\title{
Muhasebe Kârları İle Hisse Senedi Fiyatları Arasındaki İlişki: BİST Firmaları Üzerine Bir Uygulama
}

\author{
Abdulkadir KAYA** \\ Meryem Öztürk***
}

\section{$\ddot{O Z Z E T}$}

Hisse senetleri yatırımcılarına sermaye kazancı ve temettü geliri sağlamaktadır. Bu nedenle firma kârları hisse senedi yatırımcılarının yatırım kararlarını ve hisse senedini fiyatını etkileyen önemli bir faktördür. Bu çalışmanın amacı, firmaların muhasebe kârları ile hisse senedi fiyatları arasındaki ilişkinin incelenmesidir. Bu amaçla, BISST Gıda, İçki ve Tütün Sektöründe faaliyet gösteren firmaların 2000-2013 yıllarında elde ettikleri muhasebe kârlart ile hisse senedi fiyatlar arasında ilişki panel eşbütünleşme ve Granger nedensellik testi kullanılarak ele alınmıştır. Analiz sonucunda muhasebe kârları ile hisse senedi fiyatlarının eşbütünleşik olduğu ve muhasebe kârlarını temsil eden aktif kârlılı̆̆ı ve net kâr marjı değişkenlerinden hisse senedi fiyatı değişkenine doğru tek yönlü, esas faaliyet kârlılı̆̆ değişkeni ile hisse senedi fiyatı değişkeni arasında iki yönlü nedensellik tespit edilmiştir.

Anahtar Kelimeler: Hisse senedi fiyatları, muhasebe kârları, Granger nedensellik testi. JEL Sinıflandırması: G10, G20, M41.

\section{The Relationship Between Accounting Profits And Stock Prices: An Application On} BIST Firms

\section{ABSTRACT}

Stocks provide to investors capital gain and dividend income. Therefore the company profit is an important factor that affects investment decisions of stock investors and stock price. The aim of this study is to investigate relationship between accounting profit and stock prices. For this aim relationship between stock prices and accounting profits of companies operating in BIST Food, Beverage and Tobacco Sector over the period of 2000-2013 is investigated by using panel cointegration analysis and Granger causality test. As a result of analysis, it was determinated cointegration between accounting profit and stock pricies and single direction causality from variables of asset profit and net profit marjin that that represents accounting profits to stock price variable and bidirectional causality between operating profit variable and stock price variable.

Keywords: Stock prices, accounting profits, Granger causality test.

Jel Classification: G10, G20, M41.

\footnotetext{
** Yrd. Doç. Dr. Abdulkadir Kaya, Erzurum Teknik Üniversitesi, İktisadi ve İdari Bilimler Fakültesi, akadirkaya@erzurum.edu.tr

*** Yrd. Doç. Dr. Meryem Öztürk, Atatürk Üniversitesi, Açıköğretim Fakültesi, meryemozturk61@gmail.com
} 


\section{GİRIŞ}

Hisse senetleri piyasasında yatırımcıların kararlarının belirlenmesindeki en önemli göstergelerden biri kuşkusuz hisse senetlerinin fiyatlarıdır. Hisse senetleri riskli yatırım araçları olduklarından yatırımcılar risklerden korunmak ve daha fazla getiri elde edebilmek için hisse senedi fiyatlarını etkileyen faktörler ve bu faktörlerin hisse senedi fiyatını ne ölçüde etkileyebileceği hakkında bilgi sahibi olmayı isterler. Hisse senedi fiyatlarını etkileyen faktörlerin bilinmesi, hisse senedi hareket yönünün başarılı bir şekilde tahmin edilmesi ve yatırımcıların verecekleri kararların sağlıklılığı açısından önem arz etmektedir. Çünkü bu faktörlerdeki değişime bağlı olarak hisse senedi fiyatları değişim gösterecektir (Ayaydın ve Dağl1, 2012: 46).

Hisse senedi fiyatını etkileyen faktörler genel olarak makro faktörler ve mikro faktörler olarak sınıflandırılmaktadır. Makro faktörler, faiz oranları, döviz kuru, para arzı, ekonomik durgunluk, sanayi üretim endeksi, enflasyon, altın, petrol fiyatları gibi ekonomik faktörlerken; mikro faktörler, firmaların finansal yapısı, muhasebe kârlarının sürekliliği, firmaların büyüklüğü, aktif toplamı içerisinde maddi duran varlıkların oranı, firma yönetimi, sermaye artırımı, kâr dağıtım politikası, içerden öğrenenlerin ticareti, işletmenin sektör içerisindeki konumu ve payı, firmaların nakit akımlarının büyüklüğü, firmalara ait finansal tablolardaki bilgilerin kalitesi gibi işletme düzeyinde ortaya çıkabilecek faktörlerdir.

Firmaların likidite, finansal yapı, varlıkların devir hızı, kârlılık ve borsa performans durumları gibi firmalara özgü faktörlerin değerlendirilmesi, ilgili firmalara ilişkin hisse senetlerinin gerçek değerinin ne olması gerektiği konusunda yatırımcılara bilgi vermektedir. Firmaların gerçek finansal durumlarını yansıtan finansal oranlar kullanılarak hisse senedi fiyatlarının büyük oranda tahmin edilebileceği görüşü, yatırımcıları ve akademisyenleri finansal oranlarla hisse senedi getirileri arasındaki ilişkilerin tespit edilmesine yöneltmiştir (Büyükşalvarc1, 2010: 131).

Yapılan araştırmalar yatırımcıların muhasebe rakamları içinde işletmenin bir yıllık performansını ve gelecekteki nakit akımları ile nakit yaratma yeteneğindeki değişmeleri işaret eden, finansal durumu özetleyen ve çoğu zaman bir performans ölçüsü olarak kullanılan (Özer, 1996: 152-153), bir anlamda bileşke rakam olan muhasebe kârlarının çok yüksek oranda önem taşıdığını, firmalarla ilgili olarak yapılan finansal analizlerde kullanılan en yaygın ölçü olma özelliğini geçmişten bugüne sürdürdüğünü ve yatırımcıların kanılarının değişmesine ve hisse senedi fiyat hareketlerinin oluşmasına yol açtı̆̆ını ortaya koymaktadır (Özer ve Yücel, 2005: 2).

Bu bağlamda çalışmanın amacı, BİST'de Gıda, İçki ve Tütün Sektöründe faaliyet gösteren işletmelerin muhasebe kârları ile hisse senedi fiyatları arasında ilişki olup olmadığını tespit etmektir. Bu amaçla öncelikli olarak değişkenler arasında uzun dönemli bir ilişkinin olup almadığı belirlenecek, uzun dönemli bir ilişki olması durumunda değişkenler arasında nedensellik testi yapılacaktır. 


\section{LITERATÜR}

Bu çalışmada firmaların muhasebe kârlarının hisse senedi fiyatları üzerindeki etkisi ile ilgili literatür incelendiğinde bu konuda genellikle, firmaların finansal tablolarından hesaplanmış olan finansal oranlarının, hisse senedi fiyatları, hisse senedi getirileri üzerindeki etkilerinin ele alındığı görülmektedir. Bu konularda yapılan literatür çalışmaları aşağıda özetlenmiştir.

Dehuan ve Jin (2008), Çin'deki firmaların hisse senedi fiyatları üzerinde işletme performansının etkili olup olmadığı araştırmak üzere yaptıkları çalışmalarında Shanghai Menkul Kıymetler Borsasında faaliyet gösteren işletmelerden 1996-2000 döneminde en yüksek \%10'luk performansa (yıllık hisse senedi getirisine) sahip olanları analize dâhil etmiştir. Hisse senedi getirileri üzerinde toplam varlık devir hızı, hisse başına kârdaki değişme, kâr marjı, aktif kârlılığı, özsermaye kârlılığı, satışlardaki değişme oranının etkisi olup olmadığ basit ve çoklu regresyon analizi ile test edilmiştir. Basit regresyon analizi sonuçlarına göre, özsermayenin kârlılığının beş yıllık uygulama döneminin dördünde, hisse başına kârdaki değişmenin beş yıllık uygulama döneminin üçünde hisse senedi getirilerini açıklama gücüne sahip olduğunu göstermektedir. Kâr marjı, aktif kârlılığ1, satışlardaki değişme ve toplam varlık devir hızının hisse senedi getirilerini açıklama gücüne sahip olduğunu belirtmiştirler.

Aktaş (2008), hisse senedi getirileri ile ilişkili olduğu düşünülen finansal oranları belirleyerek yüksek performans gösteren hisse senetlerinin seçimine katkı sağlamak amacıyla yaptığı çalışmada, İMKB'de 1995-1999 ve 2003-2006 olmak üzere iki ayrı analiz dönemini kullanmış, 1995-1999 y1lı için 91, 2003-2006 yılları arası için 158 firmanın veri setinden yararlanmıştır. Hisse senedi getirileri ile önemli derecede ilişkiye sahip olan finansal oranları belirleyebilmek için lojistik regresyon analiz yönteminin uygulandığ 1 araştırmada, bağımlı değişken olarak hisse senedi getirileri, bağımsız değişken olarak ise likidite, finansal yapı, nakit akımı, faaliyet ve kârlılık oranlarından oluşan 20 finansal oran kullanılmıştır. Çalışmanın sonuçlarına göre, 1995-1999 döneminde orta vadede hisse senedi getirileri ile ilişkili olan finansal oranların; asit test ve faaliyetlerden sağlanan nakit akımı/özsermaye oranı, 2003-2006 döneminde ise brüt kâr/satışlar ve net kâr/satışlar oranının olduğu tespit edilmiştir.

Korkmaz ve Karaca (2013) yaptıkları çalışmada, hisse senedinin yıl sonu kapanış fiyatı ve hisse getiri oranı ile nakit kâr payı dağıtım oranı, aktif kârlılığı, fiyat/kazanç oranı, hisse başına kâr, net kâr büyümesi, piyasa değeri/defter değeri, piyasa değeri özsermaye kârlılığı değişkenleri arasındaki ilişkiyi İMKB 30 endeksine dahil 16 firma üzerinde 19982010 yılları için panel regresyon modeli ile analiz etmişlerdir. Çalışmada iki model kurulmuştur. İlk modelde hisse kapanış fiyatı bağımlı değişken olarak belirlenmiştir. Hisse senedi kapanış fiyatını, temettü ödeme oranındaki ve hisse başına kârdaki değişimin arttırdığ aktif kârlılı̆̆ındaki değişimin azalttığı ve piyasa değeri/defter değeri ile piyasa değerindeki 
artışın ise hisse kapanış fiyatını etkilemediği sonucuna ulaşılmıştır. Hisse senedi getiri oranın bağımlı değişken olarak belirlendiği ikinci modelde ise hisse getiri oranını, piyasa değeri artışı ve hisse başına kâr artırırken, aktif kârlılığının etkilemediği gözlenmiştir.

Omran ve Ragab (2004), hisse senedi getirileri ile finansal oranlar arasındaki ilişkiyi belirlemek üzere Mısır'da faaliyet gösteren 46 firma için 1996-2000 dönemini dikkate alarak gerçekleştirdikleri çalışmalarında, bağımlı değişken olarak hisse senedi getirileri, bağımsız değişken olarak ise likidite, faaliyet, kârlılık, kaldıraç ve sabit giderleri karşılama oranlarını kullanmıştır. Çalışmalarında kurdukları doğrusal model sonuçları, özsermaye kârlılığı ile hisse senedi getirisi arasında önemli bir ilişki olduğu, finansal oranlarla hisse senedi getirileri arasında doğrusal olmayan ilişkilerin var olduğu ve doğrusal olmayan ilişkilerin doğrusal ilişkiye göre hisse senedi getirilerini daha iyi bir şekilde açıkladığını ortaya koymaktadır.

Demir (2001) yaptığ çalışmada, hisse senedi fiyatını belirleyen işletme düzeyindeki faktörleri İMKB'de mali sektör bazında incelemiştir. 1991-2000 y1lları arasında 16 işletme üzerinde çoklu regresyon yönteminin kullanıldığı araştırmada hisse senedi fiyatları bağımlı değişken, kaldıraç oranı, özsermaye kârlılığı, aktif kârlılığ1, temettü ödeme oranı, fiyat/kazanç, piyasa değeri/defter değeri, işlem görme oranı, hisse başına kâr, net kâr artış hızı ve özsermaye artış hızı bağımsız değişken olarak ele almıştır. Çalışmanın sonucunda mali sektör hisse senedi fiyatını etkileyen işletme düzeyindeki faktörlerin piyasa değeri/defter değeri, hisse başına kâr, fiyat/kazanç oranı, özsermaye kârlılığı, kaldıraç oranı, net kâr artış hızı, işlem görme oranı ve temettü ödeme oranı olduğunu belirlemiştir.

Hisse başına kazanç, hisse başına net varlık değeri, özsermayenin kârlılığ1, fiyat/kazanç oranı gibi muhasebe bilgilerinin Kolombiya Menkul Kıymetler Borsasında 20072011 yılları arasında hisse senetleri işlem gören üretim işletmelerinin hisse senedi fiyatlarının değer ilişkisine ait ampirik kanıtlar sağlamak üzere yaptıkları çalışmada Vijitha ve Nimalathasan (2014), regresyon analizini kullanmıştır. Çalışmanın bulgularına göre, Hisse başına kâr, hisse başına net varlık değeri, özsermayenin kârlılığının \%1 önem düzeyinde hisse senedi fiyatları ile önemli ölçüde ilişkili olduğunu ortaya koymaktadır.

2005-2011 dönemi içerisinde verilerine ulaşılabilen İMKB Mali Sektör firmalarını baz alarak yaptığı çalışmasında Kayalıdere (2013), muhasebe bilgileri ile firma piyasa değeri arasındaki ilişki düzeyini araştırmıştır. Araştırma yöntemi olarak firma değerini, muhasebe bilgilerinin (hisse başına kâr, hisse başına defter değeri) fonksiyonu şeklinde modelleyen Ohlson yaklaşımı kullanılmıştır. Araştırma bulgularına göre, analiz dönemi ve gözlem kümesi bağlamında muhasebe bilgilerinin firma piyasa değerinin oluşumunda belirleyici faktörlerden biri olduğu ampirik olarak gözlenmiştir.

Şamiloğlu (2005), hisse senetleri İMKB'de işlem gören deri ve gıda sektöründeki firmaların hisse başına getirileri ve hisse senedi fiyatları ile dönem kârları, nakit akımları, hisse başına kârları ve hisse başına defter değerleri arasındaki ilişkiyi incelemiştir. Çalışmada 1999-2002 döneminde 58 firmanın verileri ile üç ayrı çoklu regresyon modeli 
oluşturulmuştur. Araştırma sonucunda, firmaların genel olarak hisse getirileri ile faaliyet kazançları, faaliyet kazançlarındaki değişim, nakit akımları, nakit akımlarındaki değişim, yıllık büyüme ve yıllık büyümedeki değişim arasında düşük düzeyde bir ilişki bulunurken, hisse fiyatları ile hisse başına kazanç ve hisse başına defter değerleri arasında anlamlı bir ilişki olduğu belirlenmiştir.

Hisse senedi getirileri ile muhasebe bilgileri arasındaki değer ilişkisini tespit etmek üzere yaptıkları çalışmada Martani ve Khairurizka (2009), muhasebe bilgisini temsilen kârlılık, likidite, kaldıraç, piyasa oranı, işletme büyüklüğü, nakit akımlarını kullanmıştır. 2003-2006 yılları arasında Jakarta Menkul Kıymetler Borsasına kayıtlı üretim sektöründe faaliyet gösteren işletmeler üzerinde yapılan araştırmanın bulguları, kârlılık, devir hızı ve piyasa rasyolarının hisse senedi getirileri üzerinde önemli bir etkiye sahip olduğunu göstermektedir.

Özer ve Karbuz (2002), hisse senetleri İMKB'de işlem gören firmaların yıllık kârları ile hisse senedi getirileri arasındaki eş zamanlı ilişkiyi analiz etmişlerdir. 1993-2000 yıllarını kapsayan araştırmanın sonuçlarına göre, kârın düzeyi ve kârlardaki değişmenin birbirlerinden bağımsız olarak hisse senedi getirilerini önemli oranda açıkladığını ve bununla birlikte hisse senedi getirilerinin açıklanmasında kârlarda meydana gelen değişmenin, kârların düzeyinden daha önemli olduğu tespit edilmiştir.

İMKB'de işlem gören ve imalat sektöründe faaliyet gösteren 73 firmanın 1990-2009 yılları arasındaki verileri kullanılarak yaptıkları çalışmada Aydemir, Ögel ve Demirtaş (2012), hisse senedi fiyatlarının belirlenmesinde etkili olan finansal oranların belirlenmesini amaçlamışlardır. Panel veri yönteminin kullanıldığı çalışmada, kârlılık ve likidite oranlarının hisse senedi getirileri üzerinde pozitif bir etkiye sahip oldukları, faaliyet oranlarının ise hisse senedi getirisini etkilemediği sonucuna varmışlardır.

Martikainen (1989), hangi ekonomik boyutların (kârlılık, faaliyet kaldıracı, finansal kaldıraç ve işletme büyümesi) hisse senedi fiyatlarında etkili olduğunu belirlemek üzere 1974-1986 yılları arasında Helsinki Menkul Kıymetler Borsasında hisse senetleri işlem gören işletmeler üzerine yaptığı araştırmasında 26 işletmenin verilerinden yararlanmıştır. Araştırmanın sonuçları, finansal rasyoların hisse senedi fiyatını açıklama gücünün, raporlama günü yaklaştıkça artma, mali tabloların açıklanmasından sonraki günlerde ise azalma eğiliminde olduğu gözlemlenmiştir. Ampirik kanıtlar güçlü bir şekilde finansal rasyoların hisse senedinin fiyat ilişkilerini temsil ettiğini göstermektedir.

Uluyol ve Türk (2013) hisse senetleri BİST’te işlem gören 56 üretim işletmesinin 2004-2010 yılları arasındaki finansal verilerinden hareketle finansal rasyoları ile firma değeri arasında ilişki olup olmadığı panel veri analizi ile incelemişlerdir. Analiz sonucunda cari oran ve nakit oranının firma değeri üzerinde etkin oldukları belirlenmiştir. Stok devir hızı, öz sermaye oranı, net kâr marjı oranı ve hisse başına kâr oranları ile firma değeri arasında anlamlı bir ilişki olmadığını belirlemişlerdir. 
Karaca ve Başcı (2011), İMKB 30 endeksinde yer alan ve 2001-2009 yılları arasında süreklilik arz eden 14 firmanın yıllık mali tabloları ve aynı tarihler için hisse senedi kapanış fiyatlarından yararlanılarak yaptıkları çalışmada hisse senedi getirileri ile ilişkili olan finansal oranları incelemek ve kurulacak modeller ile yatırımcılara yön gösterebilmeyi amaçlamışlardır. Panel veri analizinin kullanıldığı çalışmanın sonuçlarına göre, kârlılık rasyoları ile hisse senedi fiyatı arasında bir ilişki olduğu ve bu ilişkinin net kâr marjı ve esas faaliyet kâr marjı açısından pozitif yönde olduğu belirlenmiştir.

Birgili ve Düzer (2010), 2001-2006 yılları arasında İMKB'de faaliyet gösteren 58 firma üzerinde panel veri analizi kullanılarak yaptıkları analizde finansal oranlar ile firma değeri arasında ilişki olup olmadığı bu oranlar vasıtasıyla likidite durumunun, mali yapının, varlıkların etkin kullanımının, kârlılığın, borsa performansının firma değeri üzerindeki etkisi incelenmiştir. Bağımlı değişken olarak firmaların piyasa değeri, bağımsız değişken olarak ise likidite oranları, mali yapı oranları, faaliyet oranları, kârlılık oranları ve borsa performans oranlarının kullanıldığ borsa performans oranları içerisinde yer alan tüm oranlar ile faaliyet oranlarından stok devir hızı, özsermaye devir hızı ve döner sermaye devir hızı, kârlılık oranlarından faaliyet kârı/net satışlar, özsermaye kârlılığı ile firma değeri arasında anlamlı bir ilişki olduğu görülmüştür.

Kohansal vd. (2013), 1992-2010 yılları arasında İran Menkul Kiymetler Borsasında faaliyet gösteren gıda işletmelerinin hisse senedi fiyatları üzerinde finansal rasyoların etkisi olup olmadığı üzerine yaptıkları çalışmada likidite rasyoları, faaliyet rasyoları, kârlılık rasyoları ve finansal kaldıraç rasyoları bağımsız değişken olarak kullanmıştır. Çalışmanın sonuçları, likidite rasyoları, aktif kârlılığı, özsermaye kârlılığının hisse senedi fiyatlarını açıklamada önemli değişkenler olduğunu göstermektedir.

Özer (1996), İMKB'de 1988-1991 y1llarına ilişkin 231 gözlem üzerinde yaptığ1 çalışmada, hisse senedi verimleri ile muhasebe kârları arasındaki ilişki ve bu ilişkiye etki eden faktörleri (kâr unsurları, firma büyüklüğü ve zaman) analiz etmiştir. Hisse senedi verimleri ile kârlardaki beklenmeyen değişmelerin işareti arasındaki ilişkinin belirlenmesinde ki-kare testi, diğer ilişkiler ve parametrelerdeki farklılıkların belirlenmesinde ise regresyon (tek değişkenli ve çok değişkenli) yöntemi kullanılmıştır. Araştırmanın bulgularına göre, kârlar ile hisse senedi fiyatları arasında aynı yönde, doğrusal ve istatistiki olarak anlamlı bir ilişki olduğu belirlenmiştir.

İMKB 30 endeksinde işlem gören firmaların hisse senedi getirilerinin ilgili dönemdeki finansal oranlarla açıklanıp açıklanamadığını lojistik regresyon analizi ile araştırmak ve hisse senedi seçiminde finansal oranların belirgin bir seçim kriteri olarak kullanılabilirliğini test etmek üzere yaptıkları çalışmalarında Ege ve Bayrakdaroğlu (2009), firmaların 2004 yılına ait yirmi finansal oranı (likidite oranları, faaliyet oranları, kârlılık oranları, finansal yapı oranları borsa performans oranları) bağımsız değişken ve nominal getirileri bağımlı değişken olarak kullanmıştır. Analiz sonuçlarına göre, hisse senedi getirilerini açıklamada fiyat/kazanç oranı, nakit oranı ve toplam varlıkların devir hızı oranı önemli birer bağımsız değişken olarak 
görülürken, literatürde büyük ağırlığı olan PD/DD oranı, tahmini yapılan logit modele göre önemli bir bağımsız değişken olarak görülmemiştir.

Campbell ve Shiller (1998), değerleme oranlarından kâr payı/fiyat ve kazanç/fiyat oranları ile hisse senedi fiyatı arasındaki ilişkiyi incelemiştir. 12 ülkenin uzun dönemli geçmiş piyasa verileri kullanılarak yapılan araştırma sonucunda, kâr payı/fiyat ve kazanç/fiyat oranları kullanılarak hisse senedi fiyatlarının tahmin edilemeyeceği ve aralarında doğrusal bir ilişkinin olmadığı sonucuna varılmıştır.

İMKB 100'de 1997-2008 döneminde kesintisiz olarak işlem gören 60 işletmenin mali tablo verilerinden yararlanarak hisse senedi getirileri ile çeşitli finansal oranlar (aktif devir hızı, özsermaye/toplam varlık oranı, özsermaye kârlılığı, satış büyüklüğü, varlık büyümesi, PD/DD oranı) arasındaki ilişkinin tespit edilmesine yönelik yaptığı çalışmasında Oruç (2010) portföy yaklaşımını kullanmıştır. Elde edilen sonuçlara göre, yıllar itibarıyla aktif devir hızı, satış büyüklüğü, varlık büyümesi ve $\mathrm{PD} / \mathrm{DD}$ oranının hisse senedi getirileri üzerinde etkili olduğu; özsermaye toplam varlık oranı ve özsermaye kârlılığının etkili olmadıkları görülmüştür.

\section{VERİ VE YÖNTEM}

Muhasebe kârları ile hisse senedi fiyatları arasındaki etkileşimi belirlemeyi amaçladığımız çalışmamızda kullanılan değişkenler ve değişkenlerin elde edildiği kaynaklar Tablo 1'de gösterilmiştir.

Tablo 1: Analizde Kullanılan Değişkenler

\begin{tabular}{|c|c|c|}
\hline Değişkenler & Değişkenlerin Kısaltması & Verilerin Elde Edildiği Kaynaklar \\
\hline $\begin{array}{c}\text { Aktiflerin Kârlılı̆ı } \\
\text { (Net Kâr / Toplam Aktifler) }\end{array}$ & AKAR & \multirow{2}{*}{ Kamuyu Aydınlatma Platformu } \\
$\begin{array}{c}\text { Net Kâr Marjı } \\
\text { (Net Kâr / Net Satışlar) }\end{array}$ & NKM & \\
\hline $\begin{array}{c}\text { Esas Faaliyet Kârlılığı } \\
\text { (Esas Faaliyet Kârı / Net Satışlar) }\end{array}$ & EFK & Borsa İstanbul \\
\hline Hisse Senedi Fiyatı \% Değişim & HSF & \\
\hline
\end{tabular}

Çalışma kapsamında, satışlarında yıl boyunca mevsimsellik etkilerinin ve fiyat dalgalanmalarının çok fazla olmaması nedeniyle Borsa İstanbul, Gıda, İçki ve Tütün Sektörü tercih edilmiştir. Gıda, İçki ve Tütün Sektöründe 2014 yılı itibariyle 30 firma faaliyet göstermesine rağmen çalışma dönemi olan 2003 - 2013 yılları arasında kesintisiz olarak hisse senetleri borsada işlem gören 17 firma seçilmiştir. Veri setini oluşturan firmalar Tablo 2'de sunulmuştur. 
Tablo 2: Veri Setini Oluşturan Firmalar

\begin{tabular}{|l|l|}
\hline Kisaltma & Firma İsmi \\
\hline ALYAG & ALTINYAĞ \\
\hline AEFES & ANADOLU EFES \\
\hline BANVT & BANVIT \\
\hline ERSU & ERSU GIDA \\
\hline FRIGO & FRİGO PAK GIDA \\
\hline KENT & KENT GIDA \\
\hline KERVT & KEREVITAŞ GIDA \\
\hline KNFRT & KONFRUT GIDA \\
\hline KRSTL & KRISTAL KOLA \\
\hline MERKO & MERKO GIDA \\
\hline PENGD & PENGUEN GIDA \\
\hline PETUN & PINAR ET VE UN \\
\hline PINSU & PINAR SU \\
\hline PNSUT & PINAR SÜT \\
\hline TATGD & TAT GIDA \\
\hline TUKAS & TUKAŞ \\
\hline TBORG & T.TUBORG \\
\hline
\end{tabular}

Çalışmada Tablo 2'de gösterilen 17 firmanın 2003-2013 dönemini kapsayan, AKAR, NKM, EFK ve HSF değişkenlerinin yıllık verilerinden oluşan veri seti kullanılmıştır. Firmaların hisse senetleri fiyatları değişkeni, yıl boyunca gerçekleşen hisse senedi fiyatlarının günlük kapanış fiyatlarının aritmetik ortalaması alınarak hesaplanmıştır. HSF değişkeni ise hisse senedi fiyatı olarak hesaplanan tutarlardaki artış oranları olarak hesaplanmıştır. Muhasebe kârları olarak ele alınan değişkenler ise firmaların bilanço ve gelir tablolarından elde edilen verilerden hesaplanmıştır. Yapılan analizlerde Eviews 8 ekonometri paket programı kullanılmıştır.

Muhasebe kârları ile hisse senedi fiyatları arasındaki uzun dönemli ilişkinin belirlenmesi amacıyla "panel eşbütünleşme" analizi yapılacaktır. Değişkenler arasında eşbütünleşmenin tespiti durumunda, değişkenler arasındaki nedenselliğin yönünü belirlemek amacıyla "panel granger nedensellik" testi yapılacaktır.

Zaman boyutuna sahip kesit serilerini kullanarak ekonomik ilişkilerin tahmin edilmesi yöntemine panel veri analizi adı verilmektedir. Bu analizde zaman serileri ile kesit serileri bir araya getirilerek, hem zaman hem de kesit boyutuna sahip veri seti oluşturulmaktadır. Panel veri sadece yatay kesit ya da sadece zaman serisi ile karşılaştırıldığında çeşitli avantajlara sahip bulunmaktadır. Panel veri yönteminin avantajlarını söyle sıralanmaktadır:

Panel veri kişiler, firmalar, ülkeler gibi birimlerle zaman içinde ilişki kurduğundan bu birimlerin aralarında heterojen olması kaçınılmaz olmaktadır. 
- Panel veri yatay kesit gözlemlerin zaman serisini birleştirerek daha bilgilendirici veriler, daha fazla değişkenlik, değişkenler arasında daha az doğrusallık (collinearity), daha fazla serbestlik derecesi ve daha etkin bir model sağlamaktadır.

- Tekrar eden yatay kesit gözlemlerle çalıştığından, panel veri "değişim dinamiklerini” çalışmak için daha uygun bir yöntemdir.

- $\quad$ Panel veri sadece yatay kesit ya da sadece zaman serisinde gözlenemeyen etkileri daha iyi teşhis eder ve ölçmektedir.

- $\quad$ Panel veri bize daha karmaşık davranışlara sahip modeller üzerinde çalışma imkânı sağlamaktadır (Gujarati, 2001).

Menkul kıymet piyasalarının gelişimi ve ekonomik gelişme arasındaki etkileşimi belirlemek amacıyla, değişkenler arasında uzun dönemli bir ilişkinin varlığ 1 araştırılacaktır. $\mathrm{Bu}$ konuda yapılan araştırmamızda literatürde en sık rastlanan panel veri eşbütünleşme analizlerinin, Pedroni eşbütünleşme analizi, Kao ve Johansen Fisher eşbütünleşme analizleri oldukları tespit edilmiştir. Çalışmamızda söz konusu değişkenler arasındaki eşbütünleşme, Pedroni eşbütünleşme analizi ile belirlenecektir.

Pedroni (1999) tarafindan geliştirilen analiz (1) numaralı panel regresyonundan hareketle ifade edilmektedir:

$$
y_{i t}=\alpha_{i t}+\delta_{i t} t+X_{i t} \beta_{i}+e_{i t}
$$

Denklemde yer alan $y_{i t}$ ve $X_{i t}$ sirasıyla $\left(N^{*} T\right) x 1$ ve $\left(N^{*} T\right) x m$ boyutundaki gözlemlenebilen değişkenleri vurgulamaktadır. Pedroni eşbütünleşme analizinde panel serilerinde eşbütünleşik bir ilişkinin olmadığını sınayan sıfır hipotezinin asimptotik ve sonlu gözlem özellikleri varsayımlarına dayanmaktadır. Hem uzun dönem eşbütünleşik vektörlerinde ve hem de dinamik modellerde panel seriyi oluşturan bireysel kesitler arasındaki heterojenliği ölçmeye olanak tanıyan bu eşbütünleşme analizi, iki test grubundan oluşmaktadır. İlk grubu oluşturan testler, boyutlar-içi yaklaşımı üzerine temellendirilmiş olup; panel $v$-istatistiği, panel $\rho$-istatistiği, panel PP-istatistiği ve panel ADF-istatistiği olmak üzere dört testten oluşmaktadır. Bu istatistikler, tahmin edilen kalıntı serileri üzerindeki birim kök testleri için farklı yatay kesit birimleri arasında otoregresif katsayıları birleştirmektedir. İkinci grubu oluşturan testler ise boyutlar-arası yaklaşımı üzerine inşa edilmiştir ki, toplamda üç testten meydana gelmektedirler. Bunlar; grup $\rho$-istatistiği, grup PP-istatistiği ve grup ADF-istatistiğidir. $\mathrm{Bu}$ istatistikler de her bir yatay kesit birimi için bireysel olarak tahmin edilen ortalama katsayı tahmincilerine dayanmaktadırlar (Yüce, Akıncı ve Yılmaz, 2013; Lee, 2005).

Pedroni (1999) tarafindan panel ve grup olmak üzere iki grup halinde ifade edilen test istatistikleri, sirasıyla (1), (2), (3), (4), (5), (6), (7) ve (8) numaralı denklemler yardımıyla hesaplanmaktadırlar: (Pedroni, 1999, s.660) 
- Panel v-istatistiği:

$Z_{v}=\left(\sum_{i=1}^{N} \sum_{t=1}^{T} \hat{L}_{11 i}^{-2} \hat{e}_{i, t-1}^{2}\right)^{-1}$

- Panel $\rho$-istatistiği:

$Z_{\rho}=\left(\sum_{i=1}^{N} \sum_{t=1}^{T} \hat{L}_{11 i}^{-2} \hat{e}_{i, t-1}^{2}\right)^{-1} \sum_{i=1}^{N} \sum_{t=1}^{T} \hat{L}_{11 i}^{-2}\left(\hat{e}_{i, t-1} \Delta \hat{e}_{i t}-\hat{\lambda}_{i}\right)$

- Panel PP-istatistiği:

$Z_{t}=\left(\hat{\sigma}^{2} \sum_{i=1}^{N} \sum_{t=1}^{T} \hat{L}_{11 i}^{-2} \hat{e}_{i, t-1}^{2}\right)^{-1 / 2} \sum_{i=1}^{N} \sum_{t=1}^{T} \hat{L}_{11 i}^{-2}\left(\hat{e}_{i, t-1} \Delta \hat{e}_{i t}-\hat{\lambda}_{i}\right)$

- Panel ADF-istatistiği:

$Z_{t}^{*}=\left(\hat{S}^{* 2} \sum_{i=1}^{N} \sum_{t=1}^{T} \hat{L}_{11 i}^{-2} \hat{e}_{i, t-1}^{*^{2}}\right)^{-1 / 2} \sum_{i=1}^{N} \sum_{t=1}^{T} \hat{L}_{11 i}^{-2} \hat{e}_{i, t-1}^{*} \Delta \hat{e}_{i t}^{*}$

- Grup $\rho$-istatistiği:

$\tilde{Z}_{\rho}=\sum_{i=1}^{N}\left(\sum_{t=1}^{T} \hat{e}_{i, t-1}^{2}\right)^{-1} \sum_{t=1}^{T}\left(\hat{e}_{i, t-1} \Delta \hat{e}_{i t}-\hat{\lambda}_{i}\right)$

- Grup PP-istatistiği:

$\tilde{Z}_{t}=\sum_{i=1}^{N}\left(\hat{\sigma}^{2} \sum_{t=1}^{T} \hat{e}_{i, t-1}^{2}\right)^{-1 / 2} \sum_{t=1}^{T}\left(\hat{e}_{i, t-1} \Delta \hat{e}_{i t}-\hat{\lambda}_{i}\right)$

- Grup ADF-istatistiği:

$\tilde{Z}_{t}^{*}=\sum_{i=1}^{N}\left(\hat{s}_{i}^{2} \sum_{t=1}^{T} \hat{e}_{i, t-1}^{*^{2}}\right)^{-1 / 2} \sum_{t=1}^{T}\left(\hat{e}_{i, t-1}^{*} \Delta \hat{e}_{i t}^{*}\right)$

Bu denklemlerde yer alan $\hat{e}_{i t}$, (2) numaralı denklemden elde edilen kalıntı değerlerini ve $\hat{L}_{11 i}^{2}$ ise $\Delta \hat{e}_{i t}$ için tahmin edilen uzun dönem kovaryans matrislerini ifade etmekte, aynı şekilde $\hat{\sigma}_{i}^{2}$ ve $\hat{s}_{i}^{2}\left(\hat{s}_{i}^{*^{2}}\right)$ ise sirasıyla bireysel $i$ için uzun dönem ve zamansal varyansları göstermektedir. Bu yedi test asimptotik standart normal dağılım özelliklerini bünyesinde barındırmaktadır. Panel v-istatistiğinde elde edilen büyük pozitif değerler sonucunda eşbütünleşik ilişkinin olmadığını ifade eden sıfır hipotezi reddedilirken; geri kalan diğer istatistiklerde ise yakalanan büyük negatif değerler sonucunda sıfır hipotezi reddedilebilmektedir. 
Menkul kıymet piyasalarının gelişimini temsil eden değişkenlerle, ekonomik büyüme arasındaki uzun dönem ilişsinin belirlenmesinden sonra, değişkenler arasında nedenselliğin yönünün belirlenmesi amacıyla, Granger (1964 ve 1969) tarafından geliştirilmiş ve Hamilton (1994) tarafından geliştirilmiş olan Granger nedensellik testi kullanılacaktır. Granger nedenselliğinde $\mathrm{X}$ ve $\mathrm{Y}$ gibi iki değişken arasındaki ilişkinin yönü araştırılır. Eğer mevcut $\mathrm{Y}$ değeri, $X$ değişkeninin şimdiki değerinden çok, geçmiş dönem değerleri ile daha iyi tahmin edilebiliyorsa, X değişkeninden Y değişkenine doğru Granger nedenselliğinden söz edilebilir (Charemza ve Deadman, 1993: 190). Nedenselliğin yönünün belirlenebilmesi amaciyla (9) ve (10) numaralı denklemler uygulanır.

$$
\begin{aligned}
& Y_{t}=\sum_{i=1}^{n} \alpha_{i} Y_{t-i}+\sum_{i=1}^{n} \beta_{i} X_{t-i}+u_{1 t} \\
& X_{t}=\sum_{i=1}^{n} \alpha_{i} X_{t-i}+\sum_{i=1}^{n} \beta_{i} Y_{t-i}+u_{2 t}
\end{aligned}
$$

Burada $u_{1 t}$ ve $u_{2 t}$ hata terimlerinin ilişkisiz oldukları varsayılmakta ve (9) ve (10) numaralı denklemler değişkenlerin geçmiş değerlerine bağlı olduğu kadar, kendi geçmiş değerlerinin de bir fonksiyonudur.

Menkul kıymet piyasası gelişimini temsil eden değişkenler ile ekonomik büyüme arasındaki etkinin pozitif veya negatif yönünün belirlenmesi amacıyla "panel regresyon analizi” kullanılacaktır. Standart bir panel veri analizinde bağımlı değişken için N sayıda bireyin $\mathrm{T}$ dönemlik zaman serisi verileri kullanılarak analiz yapılmakta ve genel olarak panel veri analizleri için oluşturulan denklem (11) numaralı eşitlik ile ifade edilmektedir (Kaya ve Yilmaz, 2006: 69).

$$
Y_{i t}=\beta_{1 i t}+\beta_{2 i t} X_{2 i t}+\beta_{3 i t} X_{3 i t}+\varepsilon_{i t} \quad t=1 \ldots T \text { ve } i=1 \ldots N
$$

Panel veri analizinin en basit şekli, (12) numaralı modelde gösterildiği gibi katsayıların tüm yatay kesit bireyler için sabit tutulması durumudur.

$$
Y_{i t}=\beta_{1}+\beta_{2} X_{2 i t}+\beta_{3} X_{3 i t}+\varepsilon_{i t}
$$

Fakat bağımsız değişkenlerin farklı bireyleri farklı şekilde etkilediğine inanılıyorsa (12) numaralı denklem yetersiz kalmaktadır. Bu durumda karşılaşılan temel problem başlangıç noktasının $\left(\beta_{1}\right)$ nasıl tanımlanacağıdır. Başlangıç noktası, tüm bireyler için sabit tutulabilir veya böyle bir kısıt konulmayarak, farklı yatay kesit bireyler için farklı başlangıç noktalarının olmasına izin verilebilir. Bu doğrultuda, başlangıç noktası tanımlaması için "sabit etkiler modeli" ve "tesadüfi etkiler modeli” olmak üzere iki alternatif yöntem bulunmaktadır. Panel veri analizlerinde, katsayıların birimlere ya da birimler ile zamana göre değiştiğinin varsayıldı̆̆ 1 modellere "sabit etkiler modeli" denmektedir. Modelin genel formülasyonu; birimler arasındaki farklılıkların, sabit terimde meydana gelen farklılıklarla yakalanabileceği 
üzerine temellendirilmektedir. Dolayısıyla, bu modellerde sadece sabit terim değişmekte ve sabit terim zamana göre değil, kesit bazında farklılıklar göstermektedir. Diğer bir ifadeyle zaman boyutu sabit değişken tarafindan muhafaza edilmesine rağmen, bireyler arasındaki davranışlarında farklılık göstermektedir (Yüce Akıncı, Akıncı ve Yılmaz, 2013: 86-87 ; Pazarlığlu ve Gürler, 2007: 37-38). Sabit etkiler modeli genel olarak (13) numaralı denklem ile gösterilebilmektedir. (Judge, 1985: 519)

$$
y_{i t}=\bar{\beta}+\alpha_{i}+\beta_{1} X_{1 i t}+\ldots+\beta_{k} X_{k i t}+\varepsilon_{i t} \quad i=1,2, \ldots, G \text { ve } t=1,2, \ldots, N
$$

Bu denklemde;

$$
\begin{array}{ll}
y_{i t} & =\text { bağımlı değişkeni; } \\
\bar{\beta} & =\text { ortalama sabit terimi; } \\
\alpha_{i}, & =\text { i kesiti için ortalama sabit terimden farklılığı; } \\
X_{i t} & =\text { bağımsız değişkenleri; } \\
\mathrm{i} & =\text { yatay kesit birimini; } \\
\mathrm{t} & =\text { zamanı; } \\
\varepsilon_{i t} & =\text { hata terimini göstermektedir. }
\end{array}
$$

(13) numaralı denklemde yer alan hata terimi ile açıklayıcı değişkenler arasında bir ilişkinin söz konusu olması ve kesit sayısının az ve gözlem sayısının büyük durumunda sabit etkiler modelinin kullanılması daha doğru ve uygun olmaktadır.

Tesadüfi etkiler modeli ise "hata bileşenleri yaklaşımı" şeklinde de ifade edilmektedir. Tesadüfi etkiler modelinde her bir kesit birimi için farklı trend değerlerinin söz konusu olduğu, bu trend değerlerinin zaman periyodu boyunca sabit kaldığı ve açıklanan ile açıklayıcı değişkenler arasında geçici bir yatay kesit ilişkisinin varlığı öne sürülmektedir. $\mathrm{Bu}$ bağlamda, tesadüfi etkiler modelinin temel farklılığı; bireysel yatay kesit birimi için geçerli olan trend değerlerinin, $\alpha$ gibi ortak bir trend değerinden kaynaklanıyor olması ve rassal değişimi yaratan $\varepsilon_{i}$ 'nin yatay kesitler boyunca değişip, belli bir dönem aralığında sabit kalmasıdır. Böylece ${ }^{\varepsilon_{i}}$, ortak trend terimi olan $\alpha$ 'dan hareketle hesaplanabilen her bir yatay kesit biriminin rassal sapmasını ölçmektedir (Yüce, Akıncı ve Yılmaz, 2013 ;Brooks, 2008, s.498). Tesadüfi etkiler modeli genel olarak (14) numarada gösterilen eşitlik yardımıyla ifade edilmektedir: (Wooldridge, 2009, s.489)

$$
y_{i t}=\beta_{0}+\beta_{1} X_{1 i j}+\ldots+\beta_{k} X_{k i j}+\alpha_{i}+\varepsilon_{i t}
$$




\section{BULGULAR}

Firmaların muhasebe kârları ile hisse senedi fiyatları arasındaki uzun dönemli ilişkiyi belirlemek amacıyla Pedroni eşbütünleşme analizi kullanılacak, değişkenler arasındaki nedenselliğin yönünün belirlenmesi amacıyla panel Granger nedensellik testi yapılacaktır.

Ekonometrik analizlerde kullanılan serilerin durağan özellikler taşıması çok önemlidir. Durağan olmayan serilerle yapılan analizler sahte (superious) tahmin sonuçları vermektedir. Granger ve Newbold (1974)'a göre durağan olmayan veriler ile çalışılması durumunda incelenen değişkenler arasında elde edilen ilişki güvenilir olamamaktadır. $\mathrm{Bu}$ nedenle regresyon çözümlemesinden önce durağanlığın kontrol edilmesi gerekir.

Tablo 3: Panel Veri Birim Kök Testi Sonuçları

\begin{tabular}{|l|c|r|c|c|c|}
\hline \multicolumn{7}{|c|}{ Sabitli ve Trendli } \\
\hline \multirow{2}{*}{ Yöntem } & Değişken & t istatistiği & Olasılık & $\begin{array}{c}\text { Kesit } \\
\text { Sayısı }\end{array}$ & $\begin{array}{c}\text { Gözlem } \\
\text { Sayısı }\end{array}$ \\
\hline \multirow{3}{*}{$\begin{array}{l}\text { Levin, } \\
\text { Lin and }\end{array}$} & AKAR & $-10,87$ & 0,000 & 17 & 163 \\
\cline { 2 - 6 } & NKM & $-11,22$ & 0,000 & 17 & 162 \\
\cline { 2 - 6 } & EFK & $-8,946$ & 0,000 & 17 & 167 \\
\cline { 2 - 6 } & HSF & $-13,167$ & 0,000 & 17 & 161 \\
\hline
\end{tabular}

Tablo 3, çalışmaya konu olan AKAR, NKM, EFK ve HSF değişkenlerine ait panel verilerin birim kök testi sonuçlarını göstermektedir. Birim kök testi bulgularına göre tüm değişkenlerin seviye değerlerinde durağan oldukları belirlenmiştir.

Firmaların muhasebe kârlarını temsilen kullanılan AKAR, NKM ve EFK değişkenleri ve HSF değişkenlerinden oluşturulan veri setinin uzun dönemli ilişkisinin belirlenmesi amacıyla yapılan Pedroni eşbütünleşme Testi sonuçları Tablo 4'de gösterilmiştir. Tablo 4 incelendiğinde, ilgili değişkenler arasında eşbütünleşmenin varlığını yani değişken arasında uzun dönemli bir ilişkinin söz konusu olduğunu görülmektedir.

Tablo 4: Pedroni Panel Eşbütünleşme Test Sonuçları

\begin{tabular}{|c|c|c|}
\hline \multicolumn{3}{|c|}{ GELIŞMIŞ ÜLKELER } \\
\hline Test & İstatistik Değeri & Olasılık \\
\hline Panel $v$ İstatistiği & $-2,887$ & 0,999 \\
\hline Panel rho İstatistiği & 2,394 & 0,992 \\
\hline Panel $P P$ İstatistiği & $-4,137$ & 0,000 \\
\hline Panel $A D F$ İstatistiği & $-4,109$ & 0,000 \\
\hline Grup rho İstatistiği & 4,289 & 1,000 \\
\hline Grup $P P$ İstatistiği & $-4,363$ & 0,000 \\
\hline Grup $A D F$ İstatistiği & $-4,355$ & 0,000 \\
\hline \multicolumn{3}{|c|}{$\begin{array}{l}\text { Eşbütünleşik ilişkilerin varlığını ortaya koyabilmek amacıyla hesaplanan } \\
\text { istatistik değerleri, Barlett Kerneli göz önünde bulundurularak Newey-West } \\
\text { Bandwith seçimine göre belirlenmiştir. İlgili değişkenlerin optimum } \\
\text { gecikme uzunlukları ise SIC kriteri dikkate alınarak hesaplanmıștır. }\end{array}$} \\
\hline
\end{tabular}


Panel veri değişkenleri arasında uzun dönemli bir ilişkinin bulunması, bu iki değişken arasında en azından tek yönlü de olsa bir nedensellik ilişkisinin olabileceğini ortaya koymaktadır. Değişkenler arasındaki nedenselliğin varlığının belirlenebilmesi için panel Granger nedensellik testi uygulanacaktır. Granger nedensellik testinin yapılabilmesi için HSF ile AKAR, NKM ve EFK değişkenleri için oluşturulan model için uygun gecikme uzunluğunun belirlenmesi gerekmektedir. Oluşturulan modelin uygun gecikme uzunluklarının tespit edilebilmesi için modellerin en düşük bilgi kriteri belirlenmelidir. Tablo 5, modelden tespit edilmiş bilgi kriterlerini göstermektedir.

Tablo 5: Uygun Gecikme Uzunlukları

\begin{tabular}{|c|c|c|c|}
\hline $\begin{array}{c}\text { Gecikme } \\
\text { Uzunlukları }\end{array}$ & $\begin{array}{c}\text { Phillips- } \\
\text { Perron Bilgi } \\
\text { Kriteri (FPE) }\end{array}$ & $\begin{array}{c}\text { Akaike Bilgi } \\
\text { Kriteri (AIC) }\end{array}$ & $\begin{array}{c}\text { Hannan-Quinn } \\
\text { Kriteri (HQ) }\end{array}$ \\
\hline 0 & 1,440 & $-6,704$ & $-6,658$ \\
\hline 1 & 1,390 & $-6,740$ & $-6,509$ \\
\hline $2 *$ & $\mathbf{6 , 7 4 0}$ & $-7,466$ & $-7,050$ \\
\hline 3 & 7,400 & $-7,379$ & $-6,778$ \\
\hline 4 & 8,370 & $-7,269$ & $-6,483$ \\
\hline 5 & 1,010 & $-7,105$ & $-6,134$ \\
\hline 6 & 1,090 & $-7,056$ & $-5,900$ \\
\hline \multicolumn{2}{|c|}{$\begin{array}{l}(*) \text { en düşük bilgi kriterinin olduğu bilgi kriterini ve kalın } \\
\text { olarak belirtilmiş gecikme uzunluğu ise en uygun gecikme } \\
\text { uzunluğunu göstermektedir. }\end{array}$} \\
\hline
\end{tabular}

Tablo 5 incelendiğinde, en düşük bilgi kriteri değerinin gerçekleştiği "2" nin Granger nedensellik testi için kullanılacak uygun gecikme uzunluğu olduğu tespit edilmiştir.

Firmaların hisse senedi fiyatları ile muhasebe kârları için yapılan Granger nedensellik test sonuçları Tablo 6'da sunulmuştur.

Tablo 6: Granger Nedensellik Testi Sonuçları

\begin{tabular}{|c|c|c|c|}
\hline Değişken Çifti & Nedenselliğin Yönü & F İstatistiği & Olasılık \\
\hline AKAR- HSF & $\rightarrow$ & 4,657 & 0,010 \\
\hline HSF - AKAR & -- & 1,878 & 0,156 \\
\hline EFK - HSF & $\rightarrow$ & 6,073 & 0,002 \\
\hline HSF - EFK & $\rightarrow$ & 2,532 & 0,082 \\
\hline NKM - HSF & $\rightarrow$ & 3,122 & 0,046 \\
\hline HSF - NKM & -- & 1,427 & 0,243 \\
\hline
\end{tabular}

Tablo 6 incelendiğinde, AKAR ve NKM değişkenlerinden HSF değişkenine doğru tek yönlü, HSF değişkeni ile EFK değişkeni arasında çift yönlü bir nedenselliğin olduğu 
belirlenmiştir. AKAR değişkeninden HSF değişkenine ve EFK değişkeninden HSF değişkenine doğru nedensellikler \% 1 önem düzeyinde, NKM değişkeninden HSF değişkenine doğru nedensellik \% 5 ve HSF değişkeninden EFK değişkenine doğru nedensellik ise \% 10 önem düzeyinde anlamlı bulunmuştur.

\section{SONUÇ}

Muhasebe kârları ile hisse senedi fiyatları arasındaki ilişkiyi belirlemek amacıyla yapılan çalışmada öncelikli olarak muhasebe kârlarını temsilen kullanılan aktif kârlılığı, esas faaliyet kârlılı̆̆ı, net kâr marjı değişkenleri ile hisse senedi fiyatı değişkenlerinin durağanlıkları Levin, Lin and Chu yöntemi ile test edilmiş, değişkenlerin seviye değerinde \% 1 önem düzeyinde durağan oldukları belirlenmiştir. Muhasebe kârlarını temsilen kullanılan değişkenleri ile Hisse Senedi Fiyatı arasında uzun dönemli ilişkinin varlığını belirlemek amacıyla Pedroni panel eşbütünleşme testi kullanılmıştır. Analiz sonucunda değişkenlerin \%1 önem düzeyinde eşbütünleşik oldukları yani muhasebe kârları ile hisse senedi fiyatları arasında uzun dönemli bir ilişki olduğu belirlenmiştir. Uzun dönemli bir ilişkinin tespit edilmesi sebebiyle değişkenler arasında bir nedensellik varlığını belirlemek amacıyla Granger nedensellik testi yapılmıştır. Analiz sonucunda muhasebe kârlarını temsil eden AKAR ve NKM değişkenlerinden HSF değişkenine doğru tek yönlü, EFK değişkeni ile HSF değişkeni arasında iki yönlü nedensellik tespit edilmiştir.

Hisse senedi fiyatlarını, borsa performanslarını ve hisse senedi verimliliklerini artırmayı amaçlayan firmalar; aktif kârlılığı, esas faaliyet kârlılı̆ğ, net kâr marjı kalemlerini artırmaya yönelik tedbirler almalı, varlık yatırımlarını ve geleceğe yönelik planlamalarını bu doğrultuda gerçekleştirmelidirler.

Diğer taraftan, hisse senedi yatırımı yapan veya yatırım yapmayı planlayan menkul kıymet yatırımcıları da, yatırım yapacakları firmaları belirlerken, yüksek getiri sağlamak ve karşılaşılabilecek zarar risklerini ortadan kaldırabilmek veya azaltabilmek için firmaların aktif kârlılı̆gı, esas faaliyet kârlılığı, net kâr marjları yüksek olan ve bu kalemlerde artış trendi göstermesi muhtemel olan firmaların hisse senetlerini tercih etmelidirler.

\section{KAYNAKLAR}

Aktaş, Metin (2008), “İstanbul Menkul Kıymetler Borsasında Hisse Senedi Getirileri İle İlişkili Olan Finansal Oranların Araştırılması”, İstanbul Üniversitesi İşletme Fakültesi Dergisi, Cilt:37, Say1.2, 2008, ss.137-150.

Ayaydın, Hasan-Dağlı, Hüseyin. (2012), “Gelişen Piyasalarda Hisse Senedi Getirisini Etkileyen Makroekonomik Değişkenler Üzerine Bir İnceleme: Panel Veri Analizi”, Atatürk Üniversitesi İİBF Dergisi, Cilt.26, Say1.3-4, ss.45-65.

Aydemir, Oğuzhan-Ögel, Serdar-Demirtaş, Gökhan (2012), "Hisse Senetleri Fiyatlarının Belirlenmesinde Finansal Oranların Rolü’, Yönetim ve Ekonomi Dergisi, Cilt.19, Say1.2, ss. 277-288. 
Birgili, Erhan- Düzer, Murat (2010), "Finansal Analizde Kullanılan Oranlar ve Firma Değeri İlişkisi: İMKB’de Bir Uygulama”, Muhasebe ve Finansman Dergisi, Say1.46, ss.74-83.

Büyükşalvarcı, Ahmet (2010), "Finansal Oranlar ile Hisse Senedi Getirileri Arasındaki İlişkinin Analizi: İMKB İmalat Sektörü Üzerine Bir Araştırma”, Muhasebe ve Finansman Dergisi, Say1. 48, Ekim, ss.130-141.

Campbell, John Y.- Shiller, Robert J. (1998), "Valuation Ratios and the Long-Run Stock Market Outlook", Journal of Portfolio Management, Vol.24, Iss.2, pp.11-17.

Charemza, W. W.-Deadman, D. F. (1993), New Directions in Econometric Practice, Edward Elgar Publishing, UK.

Dehuan, Jin- Jin, Zhenhu (2008), "Firm Performance and Stock Returns: An Emprical Study of The Top Performing Stocks Listed on Shanghai Stock Exchange", Academy of Accounting and Financial Studies Journal, Vol.12, No.1, 2008, pp.79-85.

Demir, Yusuf (2001), "Hisse Senedi Fiyatını Etkileyen İşletme Düzeyindeki Faktörler ve Mali Sektör Üzerine İMKB'de bir Uygulama”, Süleyman Demirel Üniversitesi İktisadi ve İdari Bilimler Fakültesi, Cilt.6, Say1.2, ss.109-130.

Ege, İlhan- Bayrakdaroğlu, Ali (2009), “İMKB Şirketlerinin Hisse Senedi Getiri Başarılarının Lojistik Regresyon Tekniği İle Analizi”, ZKÜ SBE Dergisi, Cilt.5, Sayı.10, ss.139158.

Granger, C. W. J. (1964), Spectral Analysis of Economic Time Series, Princeton University Press, New Jersey.

Granger, C. W. J. (1969), "Investigating Causal Relations by Econometric Models and CrossSpectral Methods”, Econometrica, Vol.37, No.3, ss. 424-438.

Gujarati, Damodar N. (1995), Basic Econometrics, Third Edition, McGraw-Hill, New York.

Hamilton, J. D. (1994), Time Series Analysis, Princeton University Press, New Jersey.

Judge, G. G. (1985), The Theory and Practice of Econometrics, 2nd edition, Wiley, USA.

Karaca, Süleyman Serdar- Başcı, Eşref Savaş (2011), "Hisse Senedi Performansını Etkileyen Rasyolar ve İMKB 30 Endeksinde 2011-2009 Dönemi Panel Veri Analizi”, Süleyman Demirel Üniversitesi İİBF Dergisi, Cilt.16, Say1.3, ss.337-347.

Kaya, Vedat-Yılmaz, Ömer (2006), "Bölgesel Enflasyon Bölgesel Büyüme İlişkisi: Türkiye İçin Zaman Serisi ve Panel Veri Analizleri”, İktisat İşletme ve Finans, Cilt.21, Say1.247, ss.62-78.

Kayalıdere, Koray (2013), "Hisse Senedi Piyasasında Muhasebe Bilgilerinin Rolü: İMKBMali Sektör Üzerine Bir Uygulama”, İşletme Araştırmaları Dergisi, Cilt.5, Sayı.1, ss. 130-151.

Kohansal, Mohammed Reza- Dadrasmoghaddam, Amir-Karmozdi, Komeil Mahjori-Mohseni, Abolfazl (2013), "Relationship Between Financial Ratios and Stock Prices for the 
Food Industry Firms in Stock Exchance of Iran”, World Applied Programming, Vol.3, No.10, pp.512-521.

Korkmaz, Özge-Karaca, Süleyman Serdar (2013), "Firma Performansını Etkileyen Faktörler ve Türkiye Örneği”, Ege Akademik Bakış, Cilt.13, Sayı.2, ss.169-179.

Lee, C. C. (2005), "Energy Consumption and GDP in Developing Countries: A Cointegrated Panel Analysis", Energy Economics, Vol.27, No.3, pp.415-427.

Martani, Dwi Mulyono-Khairurizka, Rahfiani (2009), “The Effect Financial Ratios, Firm Size, and Cash Flow From Operating Activities in the Interim Report to the Stock Return", Chinese Business Review, Vol.8, No.6, pp.44-55.

Martikainen, Teppo (1989), "Modelling Stock Price Behaviour By Financial Ratios", Rivista di Matematica per le Scienze Economiche e Sociali - Anno.12, Fascicolo.1, (Decisions in Economics and Finance, 12, 1), pp. 119-138.

Omran, Mohammed-Ragab, Ayman (2004), "Linear Versus Non-linear Relationships Between Financial Rations and Stock Returns: Emprical Evidence from Egyptian Firms", Review of Accounting and Finance, Vol.3, No.2, ss.84-102.

Oruç, Eda (2019), “İMKB’de İşlem Gören İşletmelerin Hisse Senedi Getirileri İle Çeşitli Finansal Göstergeleri Arasındaki İlişki”, Hitit Üniversitesi SBE Dergisi, Y1l. 3, Sayı.12, ss.33.43.

Özer, Gökhan (1996). Muhasebe Kârları ile Hisse Senedi Verimleri Arasındaki İlişkiler: İMKB'de Deneysel Bir Analiz, Sermaye Piyasası Kurulu Yayınları, Yayın No:31, Ankara.

Özer, Gökhan- Yücel, Rahmi (2005), "Bir Yıldan Uzun Ölçüm Dönemlerinin Düzey ve Değişim Modelleri Açısından Muhasebe Kârları ile Hisse Senedi Fiyatları Arasındaki İlişki Üzerine Etkisi”, Muhasebe ve Denetime Bakış Dergisi, Sayı.14, Ocak, ss.1-22.

Özer, Gökhan-Karpuz, Sohbet (2002), "Firma Değerlemesinde Muhasebe Kârlarının Rolü: İMKB'de Deneysel Bir Araştırma”, İktisat, İşletme ve Finans Dergisi, Cilt.17, Say1.201, ss.112-122.

Pazarlığlu, M. V. -Gürler, Ö. K. (2007), “Telekomünikasyon Yatırımları ve Ekonomik Büyüme: Panel Veri Yaklaşımı" Finans Politik \& Ekonomik Yorumlar Cilt.44, Say1.508, ss.35-43.

Pedroni, P. (1999), "Critical Values for Cointegration Tests in Heterogeneous Panels with Multiple Regressors", Oxford Bulletin of Economics and Statistics, Vol.61, S.1, pp.653-670

Şamiloğlu, Famil (2005), "Hisse Getirileri ve Fiyatlarıyla, Kazanç ve Nakit Akımları Arasındaki İlişki: Deri ve Gıda Şirketlerinde Ampirik Bir İnceleme”, Muhasebe ve Finansman Dergisi, Say1.26, ss.120-126. 
Uluyol, Osman- Türk, Veysel Eren (2013), "Finansal Rasyoların Firma Değerine Etkisi: Borsa İstanbul (BİST)'da Bir Uygulama", Afyon Kocatepe Üniversitesi İIBF Dergisi, Cilt.XV, Sayı.II, 2013, ss.365-384.

Vijitha, P.- Nimalathasan, B. (2014), "Value Relevance of Accounting Information and Share Price: A Study of Listed Manufacturing Companies in Sri Lanka", Merit Research Journal of Business and Management, Vol.2, No.1, pp.1-6.

Wooldridge, J. M. (2009), Introductory Econometrics: A Modern Approach, 4th Edition, Cengage Learning, USA.

Yüce Akınc1, Gönül - Akınc1, Merter - Yılmaz, Ömer (2013), "İktisadi Küreselleşme ve Finansal Özgürlükler Arasındaki İlişki: Bir Panel Veri Analizi”, Akademik Araştırmalar ve Çalışmalar Dergisi, Yı1:5 Sayı:9, ss.80-99. 